\title{
Compounding in Igala: Defining Criteria, Forms and Functions
}

\author{
Gideon S. Omachonu \& David A. Abraham*
}

\begin{abstract}
In spite of the fact that compounding is really pervasive in the world's languages and despite the huge volume of literatures on compounding in languages including African languages, a critical assessment of the extant literature on compounding in African linguistics reveals that providing satisfactory criteria for defining compoundhood still requires both language specific and cross-linguistic investigations for dependable linguistic generalizations. In Ígálà, in particular, not much attention has been devoted to describing compounding. The present study therefore investigates compounding in Igala, a West Benue-Congo language spoken in north central Nigeria. Defining compoundhood and distinguishing compound words in Igala, the study shows and favours semantic criteria above phonological and syntactic considerations. Compounding generally has been found to be a highly productive word formation process in Iglala in terms of forms and functions. http://dx.doi.org/10.4314/ujah.v13i2.10
\end{abstract}

\section{Introduction}

To the best of these writers' knowledge, not much attention has been devoted to describing compounding in Ígálà. Earlier works such as Armstrong's (1951) and (1965) preliminary reports on the language did not focus on the subject matter. What came closest to it, though not in-depth, is his treatment of vowel elision in some Ígálà compound words. Similarly, even Omachonu (2001) which examines morphological processes in Ígálà is not as detailed on compound word formation. In the same vein, Atadoga (2011) did not go far on 
this. His added contribution is merely a distinction between compounds and complex words in Ígálà.

In addition, even with those languages in Nigeria, for instance, in which a fair amount of attention has been devoted to the description of compounding:- Yorùbá (Bamgbose 1967, Owolabi 1995, Awobuluyi 2005, Oyebade 2007 and Taiwo 2008, 2009), İgbò (Anagbogu 1990, 1995, 2000, Nwaozuzu 1991, Oluikpe \& Nwaozuzu 1995 and Iloene 2007), Ùrhòbò (Aziza 2007) and Kọ̀ríng (Anagbogu 2003, 2011)- a critical look at the extant literature on compounding in the languages (even African linguistics in general) would reveal that providing satisfactory criteria for defining compoundhood still requires both language specific and cross-linguistic investigations for dependable linguistic generalizations. Thus phonological, syntactic as well as semantic criteria have been proposed and used in the analysis and definition of compoundhood across languages (see Lieber \& Štekauer 2009). Even though compounding is really pervasive in the world's languages to the extent that it could be said to be a universal linguistic phenomenon (Greenberg 1963:92), defining compoundhood has been somewhat controversial in some African languages (see Nwachukwu 1983 and especially Nwaozuzu 1991 for a detailed account of such controversy in Igbo studies on nominal compounds in Igbo). Against this background therefore, the present study seeks to provide answers to the following questions on compounding in Ígálà: What features characterize compounding or compound word formation in Ígálà and to what extent is compounding a productive linguistic process in the language in terms of varieties (forms) and functions?

In what follows therefore, an overview of compounding and compound word formation processes in Ígálà as well as a robust discussion of the features and criteria for defining and distinguishing compounds, especially 
nominal compounds from grammatical structures of similar constituents in the language are provided.

\section{Defining Compoundhood in Igala: An Overview}

The two major means of creating new words especially lexical categories such as nouns, verbs and adjectives in language are compounding and derivation. Compounding is a prominent word formation process which is attested when in a language two or more words are put together to form another. Compounding or composition which is the most frequently used means of producing new lexemes has its overall defining property as 'consisting of the combination of lexemes into larger words' (Booij 2007:75). Even though this may not be a universally applicable distinction, the crucial demarcation between compounds and derived words in most languages is that compounds consist of free-standing lexemes whereas derived words, in most cases, contain affixes in the form of non-lexemic morphemes (see Lieber \& Štekauer 2009). The distinction is not always so clear-cut because (1) 'a lexeme may develop into a derivational morpheme' (c.f. Booij 2007:85), and (2) the elements that make up compounds in some languages may not be free-standing words, but rather stems or roots (see also Lieber \& Štekauer 2009). However, the use of the term lexeme, Lieber \& Štekauer argue, is 'specific enough to exclude affixes but broad enough to encompass the roots, stems and free words that make up compounds in typologically diverse languages'(p.2). In Ígálà, while we take examples (1a-c) below as typical (nominal) compounds, the examples in (2ac) are considered as derived words with obvious presence of affixes (bound morphemes, prefixes) in the derivations.

\section{$\begin{array}{ll}\text { 1.a) ọ̀là \# ọ́dà } \rightarrow \text { ọlà ộdà } & \text { 2.a) ù + koche } \rightarrow \text { ùkoche }\end{array}$ word command 'law' affix learn 'lesson'}


b) ộma \# ệrẹ̀ $\rightarrow$ ọmerẹ̀ child leg 'toe'

c) ùrà \# ẹ̀dọ̀ $\rightarrow$ ùrẹ̀dọ enjoyment heart 'peace' b) á + koche $\rightarrow$ ákoche

affix learn 'learner'

c) é + koche $\rightarrow$ ékoche

affix learn 'learning'

Nominalisation or deverbal noun formation through the use of prefixes attached to verbs (affixation) as in 2 (a-c) above is a very productive derivational process in Ígálà. On the contrary, one hardly finds instances of suffixation attested in the derivational morphology of Ígálà. Besides, it appears the nominalising affixes in 2 (a-c) (prefixes ù, á \& é) have their own inherent tones as they neither go on tone copying nor polarization but the tones are either high or low as nouns in Ígálà do not begin on mid tone. However, as it relates to the compounds, the pertinent question to ask is what features define or characterize compounds as distinct from other words and grammatical structures with similar constituents in Ígálà?

In spite of the fact that compounding is common in languages and despite the overwhelmingly huge volumes of literatures available on compounds and compounding processes in languages, it is still quite appropriate to observe that there are hardly any universally accepted criteria for determining what a compound is in terms of definition, headedness and demarcation between compounds and similar grammatical structures (Lieber \& Štekauer 2009). Hence, as mentioned earlier, phonological, syntactic as well as semantic criteria have been proposed and used in the literature to identify and distinguish especially nominal compounds from grammatical structures (noun phrases \& genitive constructions of similar constituents) in languages (see Nwaozuzu 1991, Angagbogu \& Omachonu Forthcoming, etc.). 
Fabb (2001) asserts that compounds are subject to phonological as well as morphological processes which may be language specific or specific to compounds. Thus, assimilation, vowel elision and suprasegmental features like stress, tone and intonation may play very significant roles in identifying and distinguishing compounds from noun phrases in some languages. For instance, right-hand primary stress assignment for nominal compounds in English has proved to be somewhat a useful guide in determining compounding in the language (see Jones 1995, Oslen 2000, Giegerich 2006, Lieber \& Štekauer 2009). Similarly, Finney (2002) has argued for a productive process of compounding in Krio that sometimes involves the application of tonal processes of High deletion and Low spreading. However plausible the proposal for phonological criteria may be in other languages, assimilation or vowel elision and tonal behavior as the data in 1(a-c) above exhibit may not sufficiently define and distinguish compounds in Ígálà for a dependable generalization. This is because most of the nominal compounds in the language bear the same or similar tonal patterns as their grammatical counterparts of similar constituents. At best, assimilation, cliticization or vowel elision occasioned by spelling or orthographic representation as in 1(b\&c) above can only account for noun+noun compounds written together as single words. Even at that, these cannot be considered as serious criteria for compound formation in Ígálà because they are not consistently systematic in the language. For example, they can neither account for, nor distinguish noun+noun compounds such as in $3(\mathrm{a} \& \mathrm{~b})$ from their noun phrase counterparts.

\section{3.a.i) únyí ógwù 'hospital' (compound) \\ a.ii) únyí ógwù 'house of medicine (NP)}


b.i) ómu óyìbó ‘sugar’ (compound)

b.ii) ómu óyìbó ‘salt of óyìbó’/ óyìbó’s salt (NP)

The point is that orthography or spelling convention can hardly be taken as a serious criterion for compoundhood in some languages including Igala. For example, in Yorùbá, Bamgbose 1965:27-28) proposed the use of hyphens for writing $\mathrm{N}+\mathrm{N}$ constructions (nominal compounds) meant to be one word, e.g. olóri'-burúkú 'a luckless person'. Similarly, in İgbò whereas Ogbalu (1975) proposed the use of hyphens for writing nominal compounds, Nwachukwu (1983) recommended writing such $\mathrm{N}+\mathrm{N}$ constructions as separate lexical items. This means that the writing of (nominal) compounds in these and many other languages is only a matter of individual preferences among the respective scholars. The exception in Czech and Slovak where spelling has sometimes been considered an important criterion for compoundhood notwithstanding, the written form of compounds could be notoriously inconsistent in some languages (see Szymanek 1988 for such inconsistencies in English compounds: separated with a gap e.g. word list, written together e.g. wordlist, hyphenated e.g. word-list). In all, whether the results of the composition or coming together of the words, Noun+ Noun as in (1) and (3a.i\&b.i) above are written together as single words, hyphenated or separated with a gap, each represents a new conceptual unit and new lexeme created from the existing lexemes in the language, and therefore must be properly defined and accounted for as such.

Still in search of satisfactory criteria for defining compoundhood and distinguishing compounds from similar grammatical structures, Donalies (2004:76) proposed ten criteria based on his analyses of Germanic, Romance, Slavic, 
Finno-Ugric and Modern Greek constructions. Of the ten criteria given by Donalies, only three could possibly be considered most important for distinguishing compounds across languages (see Lieber \& Štekauer 2009). These are (i) stress and other phonological means, (ii) syntactic impenetrability, inseparability, and unalterability, and (iii) the behavior of the complex item with respect to inflection. As it has been argued above, phonological criteria have already been dismissed as having very limited relevance for determining compoundhood in Ígálà. This thus leaves us with only the syntactic and semantic criteria as we proceed to examine.

By syntactic impenetrability or inseparability, it means that a complex form is a compound (as opposed to a phrase) if no other element can be inserted between the two constituents (c.f. Lieber \& Štekauer 2009). In addition, unalterability which is the other syntactic criterion for compoundhood proposed in the literature relates to the modification of the non-head in a nominal compound. In English, for example, the first stem of a compound (nonhead) does not admit modification, whereas in a syntactic construction, modification of the non-head is possible. For instance, while it is possible in English to have a very black bird for a noun phrase, it is definitely not so with blackbird as a nominal compound. In all, the question to ask about these syntactic criteria is the extent to which they can define and distinguish nominal compounds from noun phrases in Ígálà. If one applies the syntactic criteria to the examples 1(ac) and $3(\mathrm{a} \& b)$ above, one would realize they produce little or no effect in distinguishing the nominal compounds from their grammatical counterparts of similar constituents. For example, in Ígálà, both ộmẹrẹ̀ 'toe' (compound) and ọ́ma ệrẹ̀ 'child of leg' (grammatical structure) behave alike in that they do not allow an insertion of any other element between 
the two constituents, and modification can only apply to the entire construction in each case, e.g. ọmẹrẹ lìle 'big toe' and ọ́ma ệrẹ̀ lìle 'big child of leg'/leg's big child. The same applies to únyí ógwù kệkẹ 'small hospital' (compound) and únyí ógwù kệkẹe 'small house of medicine or small medicine shop/store'. One can therefore conclude that even the use of syntactic criteria cannot help in the definition and demarcation since most nominal compounds resemble grammatical structures of similar constituents in the language and they behave alike in relation to certain syntactic operations.

Furthermore, if the morpho-syntactic criterion that deals with the behaviour of the complex item (compound) with respect to inflection is considered, the result would be that even though the lack of inflectional morphemes in Ígálà renders the surface forms of nominal compounds in the language identical to the free grammatical structures in terms of their morphological forms, noun plural formation as it applies to endocentric nominal compounds in the language could provide some useful insights in determining head position in nominal compounds. If, for example, one applies the rule of noun plural formation to nominal compounds in Ígálà, it is the head noun (N1) that undergoes the appropriate plural formation rule. However, this may not give a useful guide for demarcating nominal compounds from noun phrases as both categories maintain identical head position in the language.

Thus far, the picture that emerges from the foregoing is that none of the possible criteria discussed so far gives a reliable distinction between nominal compounds and grammatical structures of similar constituents in the language. We may therefore appeal to semantic criteria. Jesperson (1954), Sheard (1966), Levi (1978), Nwaozuzu (1991), Jones (1995) and Olsen (2000) have proposed 
semantic criteria for defining compoundhood. Of the semantic criteria proposed in the literature, the summary as captured in Nwaozuzu's (1991) semantic criteria for nominal compounds in Igbo may appear more relevant for the present study. For Nwaozuzu, while holding the first two criteria constant, any complement-head structure $(\mathrm{N}+\mathrm{N})$ combination that satisfies any three of these four criteria could qualify as nominal compound in Igbo: (i) unity of concept (ii) semantic specialization (iii) permanent aspect and (iv) unitary representation of concept. By unity or oneness of concept, it means a compound denotes single new idea rather than a combination of ideas suggested by the original words (the constituents) thereby naming a new semantic whole. And by semantic specialization, it means the compound refers to a combination of words which has acquired a special meaning in a language to the extent of being adjudged as, at least, having become partly lexicalized and semantically specialized that its specific referent is no longer readily predictable from the surface constituents (see Jesperson 1954, Sheard 1966 and Levi 1978). Similarly, by permanent aspect, it means the bond between elements that form a compound must be intimate, irreversible and permanent and not just a casual association. As Levi (1978) has argued, the compound 'water bug' could only name insects that have some permanent association with water such as living in it or around it and not just a mere casual association or accidental connection of falling into the water. In the same vein, ọmẹrẹ̀ 'toe' in Ígálà is a permanent part of the leg and únyí ógwù is a house permanently designated for health delivery/services, likewise únyí ùkọ́chẹ 'school' can only refer to a building or premises where teaching and learning take place on regular or permanent basis. These and many other compounds in Ígálà are given rise to by such permanent association between elements that form the compounds in the language. 
Lastly, the term 'unitary representation of concept' means, unlike in the noun phrase where the head-word alone can take the place of the entire phrase, none of the elements constituting a nominal compound can semantically and wholly stand in for the compound single handedly in the grammar of the language. As Omachonu (Forthcoming) argues, in Ígálà, ọma 'child', for instance, can stand in for the noun phrase 'óma óko' 'Oko's child or child of farm (if oko is taken to mean 'farm' instead of a personal name)' as its head-word which bears the phrase's most general meaning. The same goes for ílo 'hair' and íye 'mother' for the noun phrases ílọ àgbà 'hair of chin' and íye ốkọ 'mother of husband or husband's mother respectively. But this is not possible with their compound counterparts as each of the elements that constitute a compound cannot represent the full meaning of the compound. For example, ọma 'child' in Ígálà even as the head of the nominal compound ómoko cannot single handedly translate into 'debased fellow'-'ómoko'. Similarly, ílo 'hair' and íye 'mother' even as heads of the nominal compounds ílagbà and íyọkọ cannot single handedly translate into 'beard' ílagbà and 'mother- in-law' íyọko respectively in the grammar of Ígálà.

\section{Other Types of Compounds in Igala}

Apart from the Noun+Noun compounds as exemplified in $1(a-c)$ and $3(a \& b)$ as well as those used for illustrations in the preceding paragraph, other compound types which can equally be accounted for using the semantic criteria enunciated above are Noun+ $\operatorname{Verb}^{1}$ collocations, Noun+

${ }^{1}$ In Ígálà, most verbs are monosyllabic in structure and many of the disyllabic or polysyllabic verbs are derived through incorporation and amalgamation. Besides, verbs and adjectives are consonant initial while nouns are vowel initial in the language (See also Omachonu 2012). 
Adjective, Verb+ Verb as well as Verb+ Noun collocations as examples (4), (5), (6) and (7) below show.

4. Noun+ Verb

a) éfù \# biệne $\rightarrow$ éfù biệne

5. Noun+ Adjective stomach be.bad 'ill-manner' heart black 'sorrow'

b) owo \# n $\rightarrow$ owone

b) ola \# fe $\rightarrow$ olafe hand have 'ownership' body clean 'luck'

c) edo \# lichì $\rightarrow$ edolichì

c) edo\#kpábie $\rightarrow$ edokpábie heart fossilize 'long-suffering'heart defile 'annoyance'

6. Verb+ Verb

a) rá \# nó $\rightarrow$ ránó run chase 'pursue'

b) gwú \# lo $\rightarrow$ gwúló pull become weak 'dissolve (a cabinet)'cry a cry 'to cry'

c) dá \# tẹ́ $\rightarrow$ dátẹ

c) ne \# éjú $\rightarrow$ néjú

\section{Verb+ Noun}

a) rá \# úle $\rightarrow$ rúlé

run a run/race 'to run'

b) ro \# ákwú $\rightarrow$ rákwú cut put set apart/ aside 'consecrate' have eye 'to expect'

From their meanings or glosses, it could be seen that the words in (4), (5), (6) and (7) exhibit most of the semantic characteristics or features of compoundhood enunciated earlier above namely; unity or oneness of concept, semantic specialization, permanent aspect and unitary representation of concept. Furthermore, in (4) and (5), even though the syllable structures of the verbs and the adjectives look very much alike, the semantic realization of the words in the contexts under review would determine the meaning and class of word ascribed to each of the words. For instance, the words fe and kpábie could be used as either verbs or adjectives depending on the context and or the collocation. Besides, the words in (4) and (5) above in addition to being recognized as nominal compounds in the Ígálà lexicon behave somewhat like idiomatic expressions (constructional idioms) in that their 
meanings are not solely determined by the composition or the sum total of the meanings of the constituents (lexemes) that make up the compounds. This confirms Kavka's (2009) view that compounds can be viewed and also studied as idiomatic expressions because 'they show quite a few features and properties that are characteristic of idiomatic expressions. ...they share with idiomatic expressions the ways in which they arise, their existence proper, and their interpretation' (p.43).

In (6), most of the Verb+ Verb collocations for verbal compounds were originally serial verbs that got lexicalized over time as compound verbs (c.f. Omachonu 2012) to express somewhat new conceptual units as they function as new lexemes in the language. In the same vein, the Verb + Noun collocations in (7) are instances of noun incorporation where the noun originally functions as an argument of the verb. Even though Bybee (1985) posits that incorporation may differ from compounding in certain ways including phonological or morphological differences; e.g. segment loss (found in Tiwi incorporation words), and that the incorporation of a word may depend on its semantic class, e.g. 'in Pawnee it is mainly body part words which are incorporated' (c.f. Fabb 2001:3), we find it more plausible to interpret noun incorporation as a compounding process in Ígálà. Whereas loss of segment (vowel elision), for instance, is almost a regular feature of noun + noun compounds that are written as single words in Ígálà, incorporation compounds as found in verb + noun collocation in the language is not so restricted semantically. Hence, one finds it more plausible to classify noun incorporation in Ígálà as a kind of compounding (See example 7a-c above).

Yet, another type of compound that has been discovered to be very productive in Ígálà is synthetic compound or what some earlier writers on compounding in 
Ígálà have christened 'compound complex' word formation (Atadoga 2011, to be more precise). A Synthetic compound, in the opinion of Fabb (2001), is a compound whose head is derived from a verb by affixation, and where the non-head fulfills the function of argument or complement of the verb. Observe 8(a-c) below as they exist in Ígálà.

\section{8.a) Affix+Verb+Noun}

\section{i. á+je \# ode $\rightarrow$ ájode}

AGT eat hunting 'hunter'

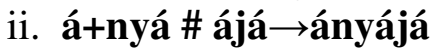

AGT bargain market 'trader' affix be.fat fat 'fatness'

iii. è+ló \# úche $\rightarrow$ èlúche iii. ù+gbó \# edo $\rightarrow$ ùgbedo

AGT cultivate farm 'farmer' affix be.strong heart 'courage'

\section{c) Noun+Affix +Verb}

\section{i. edo \# é+je $\rightarrow$ edoéje iii. epi'\# é+dá $\rightarrow$ epi édá} heart-ing eat 'patience' penis-ing cut 'circumcision'

ii. éjú \# é + fo $\rightarrow$ éjú éfo iv. edo \# e+gbó $\rightarrow$ edegbó eye-ing knead 'blindness' heart affix be.strong 'personal name'

What is synthetic in a synthetic compound in Ígálà is that it usually results from double operation which seems to take place almost simultaneously; derivation and compounding. Whereas in 8 (a), we have agent or action nouns, in 8(b), we have abstract nouns. Even though it could be argued that in Ígálà, as it relates to the data in $8(\mathrm{a} \& \mathrm{~b})$, an operation of compound formation in which the verb/noun relation that naturally looks like an argument structure (noun incorporation) occurs before the deverbal noun formation, e.g. nyájá 'to trade' before ányájá 'trader' (8a.ii) and wẹ́dò 'to be angry' before ùwẹ́dọ 'anger'(8b.i), a more intuitive and plausible explanation would be to say that derivation occurs first to achieve deverbal noun formation before compounding with the deverbal noun as head. The former 
will be a mere process of nominalization through derivation. Besides, against the English or other Germanic languages' derivational format of $[[\mathrm{N}][\mathrm{V}-\mathrm{Suffix}] \mathrm{n}] \mathrm{n}$ (where $\mathrm{N}$ is interpreted as an argument of $\mathrm{V}$ ) for synthetic compounds (Booij 2007), in Ígálà, the appropriate format for 8 (a \& b) would be to reverse the existing schema thus: [[Prefix-V] $[\mathrm{N}] \mathrm{n}] \mathrm{n}$. This is largely because of the point made earlier that Ígálà language lends itself more to prefixation whereas suffixation is hardly attested. The sequence (derivation followed by compounding) attested for synthetic compounds in Ígálà agrees with Gaeta's (2010) position that a way to deal with the two-faced nature of synthetic compounds is via derivation followed by compounding.

The difference between 8 (c) and (a \& b) is that in 8 (c), the primary nouns (mainly body parts affected in the process) precede the derived nouns (gerund) instead. There are two possible ways to interpret or analyse the head position in the synthetic compounds in 8 (c) above. The first is to assume that they are exocentric and therefore do not necessarily require a head. The second is to argue that it is possible for synthetic compounds in Ígálà to have either Right-Hand or Left-Hand head position. Unlike the derived nouns recognized as occupying head position in 8 ( $a \& b)$, the primary nouns in 8 (c), even though they refer to the parts in the body where the actions or the concepts apply, cannot serve as heads in the constructions. This is because judged by semantic interpretation; the head of a compound is a hyperonym of the compound, that is, when A denotes a set X, the head of A denotes a superset of X. This way, in line with the schema which holds that a $\mathrm{N} 1+\mathrm{N} 2$ compound in Igálà denotes a (special) kind of N1 which is the head noun (c.f. Omachonu Forthcoming), edoéje 'patience' and edegbó (though used as personal name) (8c.i\&iv) are some kinds of 
states or attributes of the heart and not kinds of heart. Similarly, éjú éfo 'blindness' (8c.ii) is a state of the eye, not a kind of eye and epi édá 'circumcision'(8c.iii) is clearly not a kind of penis but the act (an act) of removing the foreskin. By this consideration, the derived nouns in the compounds: éje, egbó, éfo, and édá which refer to attributes, states and or an act respectively qualify as heads in the construction except that instead of occupying $\mathrm{N} 1$ position as in other endocentric nominal compounds in Ígálà, they occupy N2 position. And this forms the basis of the argument that synthetic compounds in Ígálà could exhibit either Right-Hand head position or Left-Hand head position. However, the Right-Hand head rule found in 8(c.i-iv) may not be very productive in the language. It is rather an exception than the rule. This may require further investigation.

In addition, it is possible to derive, even more complex synthetic compounds in Ígálà which one may assume, do not necessarily identify with particular words as 'heads' but which contrary to the assumption go in tandem with other endocentric nominal compounds in Ígálà which have as head the first member (N1) of the constructions. In the case of the synthetic compound however the head is a derived noun (deverbal noun). Consider examples 9 (a-c) below with the same or similar derivation pattern as $8(\mathrm{a} \& \mathrm{~b})$ above.

9.a) ù- gbà- álu- te- áne $\rightarrow$ ùgbálútáne 'promise'

affix receive mouth put down

b) e- gbó- á- ne- úkpo $\rightarrow$ egbánukpò 'rag'

affix tear affix have cloth

c) ù- mà- éjú- é- che $\longrightarrow$ ùméjúéche 'skill'

affix know eye affix do

Whereas 9 (a\&c) translate as an act and a kind of knowledge respectively, 9 (b) designates a state of the cloth as being torn 
or faded to the extent of being considered as rag by ánukpò 'one who is wealth and has many clothes'.

It is important to note that synthetic compounds play a crucial role in the development of linguistic theory, since they raise a number of questions concerning the morphologysyntax interface. For instance, it has been argued that two different options are available in accounting for the argumental relation between head and modifier in synthetic compounds. It is either that lexical derivation is coupled with a syntax-driven operation which is responsible for argument inheritance or that argument inheritance simply results from semantics (c.f. Hebblethwaite 2002). The former is mostly the case for Ígálà synthetic compounds with a 'head'.

Lastly, compounding has generally been recognized as an important means of extending the lexicon of a language through the creation of new lexical categories such as nouns and verbs mainly (in Ígálà, for example). As Altmann (1988:100) has argued, "The basic motivation for forming compounds is naturally the need to express a concept not having as yet a sound form", which a speaker can use to express himself. It becomes obvious therefore that so many concepts in so many languages "may only find expression in compounds as there are needs to express these new concepts with new words" (Oluikpe \& Nwaozuzu 1995:230). Therefore, in addition to the variety of compounds discussed so far, there are two major areas in which the function of lexical expansion or extension through compounding is found very robust and highly productive in Igala. It is in the representation of foreign concepts, ideas and institutions that were hitherto non-existent in the Igala Kingdom and culture, and the use of reduplicative nominal compounding for creating new lexemes especially kinship terms in the language. In Ígálà, compounding has been used copiously in naming concepts, particularly foreign institutions, ideas, 
items/objects and concepts which have been adopted within the host culture and system. The following examples, 10 (a, b $\&$ c) will suffice.

10.a.i) únyí ùkoche 'school' house lesson

ii) únyí ógwù 'hospital' house medicine

iii) únyi' dúdú 'prison' house black

iv) únyi' àjo 'court'

house judgment

c.i) ákolà ójó 'preacher'

AGT.say.word God

iii) áko ùko (ákúko) 'teacher' iv) ákà àjo (ákàjo) 'judge'

AGT.teach instruction b.i) olàfíà àngola 'health'

fine skin

ii) ànyà ébíjè 'bicycle' horse iron

iii) oko ójálè 'aeroplane' canoe sky

iv) oko áne (okane) 'train' canoe land

ii) áte álè (átálè) 'evangelist' AGT.put AGT.go

In addition, reduplicative nominal compounds have been used to derive kinship or family tree terms in the language as shown in (11).

\section{1a. i) oma \# oma $\rightarrow$ oma oma}

child child 'grand child'

ii) íye \# íye $\rightarrow$ íye íye

mother mother 'grand mother'

iii) àtá \# àtá $\rightarrow$ àtá àtá

father father 'grand father'

iv. òókwo \# òókwo $\rightarrow$ òyíkwo òyíkwo

grand parent grand parent 'great grand parent'

\section{Summary and Conclusion}

The study examines compounding and compound word formation processes in Ígálà. It is argued that determining or 
defining compoundhood in the language favours semantic criteria above phonological and syntactic considerations. Besides, compounding generally has been found to be a highly productive word formation process in Iglala in terms of varieties (forms) and functions. Apart from noun+noun compounds, other compound types such as synthetic and verbal compounds which could equally be accounted for using semantic criteria have been attested in Ígálà. Even though endocentric nominal compounds in Ígálà generally obey Left-Hand head rule (N1 as head), synthetic compounds in Ígálà, it has been observed, exhibit the possibility for either Left-Hand head position or Right-Hand head position. However, the Right-Hand head rule found in 8(c.i-iv) may not be very productive in the language. It is adjudged as an exception rather than the rule. Lastly, in addition to the general function of lexical expansion through creation of new lexical categories or lexemes, compounding has been used copiously in naming concepts, particularly foreign institutions, ideas, items or objects and concepts that were hitherto non-existent in Igala.

*Gideon Sunday Omachonu \& David Areo Abraham are Lecturers in the Department of Linguistics and Languages, Nasarawa State University, Keffi

\section{References}

Altmann, G. 1988. 'Hypothesis about compounds'. Glottometrika, vol.x. 
Anagbogu, P. N. nominalizations

University Press.

Anagbogu, P. N 1995. 'The strong boundary condition for compounds: the Igbo perspective'. In E.N. Emenanjo \& O-M. Ndimele (eds.). Issues in African languages and linguistics: essays in honour of Kay Williamson. Aba: NINLAN Books, 246-257.

Anagbogu, P. N 2000. 'The semantic link in Igbo nominal compounding'. Journal of the linguistic association of Nigeria (JOLAN), No. 5, 40-44.

Anagbogu, P. N 2003. 'Prefixes of the Koring verb'. In O-M. Ndimele (ed.). Four decades in the study of language and linguistics: a festschrift for Kay Williamson. Aba: National Institute for Nigerian Languages. NINLAN pp. 691-699.

Anagbogu, P. N 2011. 'Introduction to morphology'. In G. S. Omachonu (ed.) NSUK texts in general linguistics. Enugu- Nigeria: Rossen Production and Services Ltd.

Atadoga, F. T. 2011. 'Igala morphology'. In G. S. Omachonu (ed.). Igala language studies. Germany: LAMBERT Academic Publishing.

Armstrong, R. G. 1951. "Igala: a preliminary report with wordlist." Institute of African Studies, University of Ibadan.

Armstrong, R. G. 1965. "Comparative wordlists of two dialects of Yoruba with Igala." The journal of West African languages II (2), 51-78.

Awobuluyi, O. 2005. Mọ́fî̀mù kan soṣo ni \{àì-\} àbí méjì. Journal of the Yorùbá studies association of Nigeria 3.1: 1-7. 
Aziza, R.O. 2007. 'Urhobo morphology'. In Ore Yusuf (ed.). Basic linguistics for Nigerian languages teachers. Port Harcourt: M \& J Grand Orbit Communications Ltd, 291304.

Bamgbose, A. 1965. Yoruba orthography: a linguistic appraisal with suggestions for reforms. Ibadan: University of Ibadan Press.

Bamgbose, A. 1967. A short grammar of Yorùbá. Ibadan: Heinemann Education Books.

Booij, G. 2007. The grammar of words. Oxford: Oxford University Press.

Crystal, D. 2008. A dictionary of linguistics and phonetics ( $6^{\text {th }}$ edn.). UK: Blackwell Publishing.

Bybee, J. 1985. Morphology. Amsterdam: John Benjamins.

Donalies, E. 2004. Grammatik des Deutschen im europäischen Vergleich: Kombinatorische Begriffsbildung. Teil 1: Substantivkomposition. Mannheim: Institut für deutsche Sprache.

Fabb, N. 2001. 'Compounding'. In A. Spencer \& A. Zwicky (eds.). The handbook of morphology. Oxford: Blackwell Publishers Ltd.

Finney, M.A. 2002. 'Compounding and reduplication in Krio'. Journal of West African languages, xxix- 2. 2334.

Gaeta, L. 2010. 'Synthetic compounds: with reference to German'. In Sergio Scalise,Irene Vogel (eds.) CrossDisciplinary Issues in Compounding. 219-236. Amsterdam: John Benjamins Publishing Co. 
Giegerich, H.J. 2006. 'Attribution in English and the distinction between phrases and compounds'. MS (To appear in Festschrift für K. F., 2006).

Greenberg, J. H. 1963. Some universals of grammar with particular reference to the order of meaningful elements. In J. H. Greenberg (ed.). Universals of language, 73-113. Cambridge Mass: MIT.

Hebblethwaite, B. 2002. 'The universality of morpho-syntax: synthetic compounding in French, English, Dutch and Korean'. Journal of universal language, 3,1-30.

Iloene, M. 2007. 'Igbo morphology'. In Ore Yusuf (ed.). Basic linguistics for Nigerian languages teachers. PH: M \& J Grand Orbit Communications Ltd, 181-194.

Jesperson, O. 1954. A modern English grammar on historical principles. London: Allen \& Unwin.

Jones, B. 1995. 'Nominal compounds and lexical rules.' Working notes of the Acquilex workshop on lexical rules. Cambridge, August, 1995.

Levi, J. N. 1978. The syntax and semantics of complex nominals. New York: Academic Press.

Kavka, S. 2009. 'Compounding and idiomatology'. In R. Lieber \& P. Štekauer (eds.) The Oxford handbook of compounding. 19-33. OUP.

Kortmann, B. 2005. English Linguistics: Essentials. Berlin: Cornelsen.

Lieber, R. \& Štekauer, P. 2009. 'Introduction: status and definition of compounding'. In R. Lieber \& P. Štekauer (eds.) The Oxford handbook of compounding. 3-18. OUP. 
Nwachukwu, P.A. 1983. Towards an Igbo literary standard. London: Kegan Paul.

Nwaozuzu, G.I. 1991. 'Igbo nominal compounds: A semantic-typological analysis'. Unpublished $\mathrm{PhD}$ Dissertation, University of Nigeria, Nsukka.

Ogbalu, F. C. 1975. 'Igbo spelling'. In F.C. Ogbalu \& E. N. Emenanjo (eds:). Igbo language and culture. Ibadan: Oxford University Press.

Oluikpe, B. \& Nwaozuzu, G.I. 1995. Igbo nominal compounds: fact or fiction? In E. N. Emenanjo \& O-M. Ndimele (eds.). Issues in African languages and linguistics: essays in honour of Kay Williamson. Aba: NINLAN Books.229-237.

Omachonu, G. S. 2001. 'Igala morphological processes'. Nsukka journal of African languages and linguistics, 2. 55-65.

Omachonu, G. S. 2012. 'Verbal Status and Serial Verb Constructions in Ígálà'. Linguistisches Kolloquium, online publication. Afrika HU Berlin.

Olsen, S. 2000. 'Compounding and stress in English: a closer look at the boundary between morphology and syntax'. Linguistische Berichte 181: 55-69.

Owolabi, Kola. 1995. 'More on Yorùbá prefixing morphology'. In Kola Owolabi (ed.) Language in Nigeria: essays in honour of Ayo Bamgbose. 92-112. İbadan: Group Publishers.

Oyebade, F. 2007. 'Yoruba morphology'. In Ore Yusuf (ed.). Basic linguistics for Nigerian languages teachers. PH: M $\&$ J Grand Orbit Communications Ltd, 241-255. 
Plag, I. 2003. Word-formation in English. Cambridge: Cambridge University Press.

Sheard, J.A. 1966. The words of English. New York: W. W. Norton.

Szymanek, B. 1988. Categories and categorization in morphology. Lublin: Katolicki Uniwersytet Lubelski.

Taiwo, O. 2008. 'Compound verbs in Yorùbá'. Studi linguistici e filologici online 6: 345-370.

Taiwo, O. 2009. 'Headedness and the structure of Yoruba compound words'. Taiwan journal of linguistics, 7.1, 2752. 